\title{
Paula Stradiņa Medicīnas vēstures muzeja apmeklētāju sastāvs (2007-2011)
}

2007. gadā Paula Stradiņa Medicinnas vēstures muzejs svinēja 50 gadu pastāvēšanas jubileju. Kopš tā laika muzeja piedāvājumu klāsts ir paplašinājies un mainījies, tāpat mainījies ir arī muzeja apmeklētājs. Šodien arvien vairāk apmeklētāju, nākot uz muzeju, ir iepriekš sagatavojušies, ieguvuši informāciju par muzeju tā mājaslapā www.mvm.lv (izveidota 2003. gadā, reorganizēta 2014. gadā), kā arī sociālajos tīklos: www.twitter.com, http:// www.draugiem.lv/mvm/ un www.facebook.com (kur muzeja publiskie konti izveidoti 2011. gada oktobrī). Tāpēc arvien svarīgāk ir noskaidrot, kādi ir muzeja apmeklētāji, lai veidotu aktuālu, interesantu un izglītojošu piedāvājumu.

Muzeja apmeklētāji galvenokārt tiek anketēti pēc respondentu kvantitatīvās metodes. Kopš 2010. gada ir noteikts mērksis aptaujāt 800 apmeklētāju gadā. Respondenti anketas aizpilda divējādi. Viens uzdevums ir noskaidrot respondentu viedokli un veikt anketēšanu muzeja telpās, taču šo pētījumu materiāli nesniedz objektīvus rezultātus dažādos jautājumos. Nelietderīgi šādi veikt aptaujas par muzeja darba laiku un ieejas maksu, jo respondents jau ir pieņēmis lēmumu apmeklēt muzeju. Tas skaidri rāda, ka viņam darba laiks un cenas ir pieņemamas. Otrs veids, kā anketēt muzeja apmeklētājus, ir anketas jautājumu ievietošana muzeja mājaslapā www.mvm.lv. Šeit var saņemt atbildes uz interesējošiem jautājumiem no potenciālajiem muzeja apmeklētājiem, respektīvi, cilvēkiem, kas vēl izvērtē, vai muzeju apmeklēt vai ne. Šajā gadījumā iespējams iegūt objektīvas 
atbildes par muzeja ieejas maksu, darba laiku, suvenīru klāstu u. tml. Turklāt, aptaujājot apmeklētājus, izkristalizējas arī viņu vēlmes - par kādām tēmām vajadzētu veidot izstādes Medicīnas vēstures muzejā. Jau vairākus gadus viena no saistošākajām tēmām apmeklētājiem ir kaut kas neizskaidrojams un mistisks, tāpēc muzejā tapušas izstādes - "Demonomānija. Nav pārdabiskais, ir tikai nezināmais", "Zilākalna Marta - mīti un patiesība".

Vēl viens veids, kā noskaidrot apmeklētāju attieksmi pret piedāvāto produktu, ir atsauksmju analizēšana un sistematizēšana. Ierakstos galvenokārt ir pateicības vārdi un laba vēlējumi turpmākajā darbībā. Salīdzinot un analizējot iegūtos rezultātus, izkristalizējas vidējais muzeja apmeklētājs, kā arī iemesli, kādēlı muzejs tiek apmeklēts.

No 2007. līdz 2011. gadam apmeklētāju skaits nav krasi mainījies, tas vienmēr ir bijis no 35 līdz 40 tūkstošiem gadā (sk. tabulu).

Medicīnas vēstures muzeja apmeklētāju skaits (2007-2011)

\begin{tabular}{|c|c|c|c|}
\hline Gads & $\begin{array}{c}\text { Kopējais } \\
\text { apmeklētāju skaits }\end{array}$ & $\begin{array}{c}\text { Ārzemnieku } \\
\text { apmeklējumi }\end{array}$ & $\begin{array}{c}\text { Bezmaksas } \\
\text { apmeklējumi }\end{array}$ \\
\hline 2007 & 35937 & 2505 & 9767 \\
\hline 2008 & 35914 & 2523 & 12880 \\
\hline 2009 & 42281 & 2039 & 25759 \\
\hline 2010 & 38007 & 3034 & 21650 \\
\hline 2011 & 37399 & 3524 & 24594 \\
\hline
\end{tabular}

Īpaši veiksmīgs bija 2009. gads, kad muzeju apmeklēja 42281 interesents. Šādu apmeklētāju skaita pieaugumu var skaidrot ar jauniem piedāvājumiem un agrāk nebijušiem pasākumiem. 2009. gadā pirmo reizi muzejs piedalījās starptautiskajā Zinātnieku naktī, kuras tēma bija "Cilvēks un Kosmoss", tāpat muzejs kopā ar vēl 13 citiem Rīgas muzejiem piedalījās gaismas festivālā "Staro Rīga" ar izstādi "Ārsts. Karavīrs. 1. pasaules karš un brīvības cīnsas”.

2009. gadā pieauga ne tikai kopējais muzeja viesu skaits, salīizinot ar 2008. gadu, kad muzeju apmeklēja 35914 interesentu, bet strauji pieauga arī bezmaksas apmeklējumu skaits - 20149 jeb 54\% no visiem muzeja apmeklējumiem. Muzeja viesu statistika liecina, ka bezmaksas apmeklējumu skaita pieaugums vērojams no 2009. gada līdz 2011. gadam, kad apmeklētāju skaits audzis ǵeometriskā progresijā. Šādu skaita 
pieaugumu var skaidrot ar muzeja rīkotajiem tematiskajiem pasākumiem un līdzdalību dažādos starptautiskos projektos, kuri parasti tiek organizēti bez apmeklētāju dalības maksas. Viens no ievērojamākajiem šāda veida pasākumiem ir starptautiskā Muzeju nakts, kurā 2011. gadā piedalījās 9000 interesentu, kā arī starptautiskā Zinātnieku nakts, kuru 2011. gadā apmeklēja 1117 interesentu. Tāpat katru gadu muzejā tiek rīkoti bezmaksas informatīvi izglītojoši pasākumi dažādām mērķauditorijām. Par ikgadējiem pasākumiem Medicīnas vēstures muzejā ir kḷuvušas Pasaules diabēta diena, Pasaules osteoporozes diena, Pasaules tuberkulozes diena, Sirds veselības diena, Zin̄̄bu diena, Starptautiskā AIDS diena, Ģimenes diena u. c. Šāda veida pasākumi, kam raksturīgs cikliskums un konkrēta tradīcija, veicina muzeja apmeklētāju dažādību ne tikai izglītības un profesionalitātes, bet arī sociālajos līmeņos.

Apmeklētāju sastāvs piecu gadu griezumā ir konsekvents. Muzeja pamata mērķauditorija ir skolēni. Viṇi veido lielāko apmeklētāju daļu. Pamatojoties uz šiem secinājumiem, tiek gatavotas atraktīvas un jauniešus saistošas izstādes, piemēram, "Skelets skapī”, "Svešais tavā ķermen̄̄”, "Nelaime nenāk brēkdama” u. c. Tāpat, pateicoties veiksmīgai sadarbībai, muzeja ekspozīciju apmeklē gan Rīgas Stradiņa universitātes studenti, gan Latvijas Universitātes topošie mediķi.

Kopš 2010. gada neliels, bet pozitīvi tendēts, ir ārzemju tūristu skaita pieaugums. Tādēl arvien vairāk resursu tiek ieguldīts, lai muzeja piedāvājums būtu pieejams svešvalodās runājošiem apmeklētājiem. Sākoties tūrisma sezonai, muzejā tiek realizēti jauni piedāvājumi, kas paredzēti ārzemju tūristiem. Vasaras sezonas plānos tiek iekļautas izstādes, kas atspoguļo muzeja krājuma bagātību un sniedz vizuālu baudījumu. Pārskata perioda laikā eksponētas izstādes "Muzeja dārgumi”, "Klau, kā zvani dimd!" Lai muzeja apmeklējumu padarītu atraktīvāku, tiek izgatavoti lielformāta fotoplakāti ar muzeja vai medicīnas vēsturē nozīmīgu sižetu, un jebkurš apmeklētājs var sevi iemūžināt skafandrā vai skeleta noformējumā.

Viens no veidiem, kā informēt sabiedrību par veselīga dzīvesveida pamatnostādnēm un Medicīnas vēstures muzeju, ir celıojošās izstādes. To apmeklētāji nākotnē kḷūst par muzeja viesiem, jo izstāde ir muzeja reklāma Latvijas lauku reǵionos, kur, iespējams, par muzeja eksistenci līdz šai izstādei nav bijusi informācija. 
Jauna un êrtāka apmeklētāju uzskaites un analīzes sistēma muzejā sākās līdz ar kases aparāta ieviešanu 2010. gada rudenī. Kḷuva ērtāk pārraudzīt jebkuras apmeklētāju darbības muzejā, līdz ar to novēršot cilvēka kḷūdas faktoru apmeklētāju uzskaitē.

2007. gadā Paula Stradiņa Medicīnas vēstures muzejs svinēja savu 50 gadu pastāvēšanas jubileju. Kopš šā laika muzeja piedāvājumu klāsts ir paplašinājies un mainījies, tāpat mainījies ir arī muzeja apmeklētājs. Svarīgi noskaidrot, kas ir muzeja apmeklētāji, tāpēc tiek veikta apmeklētāju anketēšana muzeja mājaslapā www.mvm.lv, sociālajos tīklos www.twitter.com, http://www.draugiem.lv/mvm/ un www.facebook.com, kā arī muzejā uz vietas. Analizējot aptauju rezultātus un apmeklētāju sastāvu, tiek veidots muzeja piedāvājums - izstādes, tematiski pasākumi, muzeja pedagogiskās programmas.

Lai arī no 2007. līdz 2011. gadam apmeklētāju skaits nav krasi mainījies, tomēr iezīmējas jaunas tendences - samazinās skolēnu, bet palielinās ārzemju tūristu skaits, tāpat ar katru gadu pieaug bezmaksas apmeklējumu skaits.

\section{Lienīte Šarkūna}

Paula Stradiña Medicīnas vēstures muzejs

lienite@mvm.lv 